\title{
Dobrenko, Evgeny and Natalia Jonsson-Skradol, eds. 2016. Socialist Realism in Central and Eastern European Literatures: Institutions, Dynamics, Discourses. London and New York: Anthem Press. 362 pp.
}

\author{
Reviewed by Corina L. Petrescu ${ }^{1}$, The University of Mississippi
}

The present volume is a collection of essays scrutinizing Soviet cultural policy in EastCentral Europe during the first post-World War II decade and it proposes to do so from a new perspective: one that considers "both uniformity and imposition and diversity and indigenous development" (1) when reflecting on socialist realism. In fact, these two dichotomous pairs refer back to two other instances in which researchers turned their attention to Soviet cultural policy in the region under discussion and cemented this binary approach. In the 1950s, when new academic disciplines such as behaviorism and cultural studies came about but concrete information from behind the Iron Curtain was still scarce, Western researchers tended to discuss Soviet oppression and imposition of uniformity on the entire Eastern Bloc using the same terms. Their underlying assumption was that Soviet ideology was at the core of Soviet institutions and that the satellite countries merely replicated these institutions and propagated their ideology within their own cultures. In the 1990s, after the collapse of the Soviet system, some scholars sought to question the previous premise by highlighting instances of country-specific developments. Nevertheless, generally the consensus remained that with respect to cultural policy in the Eastern Bloc external imposition led to internal compliance.

Nearing the thirtieth anniversary of the fall of the Berlin Wall in 1989, the present volume convincingly makes the argument for a more nuanced and combined approach to socialist realism. The editors, Evgeny Dobrenko and Natalia Jonsson-Skradol, justify their endeavor from a historical and thematic perspective and raise the following questions: "To what extent did the local versions of socialist realism actually originate in the pre-war traditions of the respective countries, and to what extent did they emerge from the political necessity of the moment? Were the new cultural institutions in any way grounded in the local traditions, or were they constructed to create these very traditions? Were the local actors actually actors, swept up in the 'youthful enthusiasm for a Communist future' [...], or were they merely pawns in the hands of the Soviets?" (2). Experts on various cultures of the Eastern Bloc-Soviet, East German, Polish, Czech, Slovak, Hungarian, Romanian, Bulgarian, Yugoslav but also Croatian-show how even distinctly Soviet concepts, while being imported from Moscow and sounding uniform in all these countries, designated significantly different realities in each country. Even the

${ }^{1}$ petrescu@olemiss.edu

(cc) BY

ULLS D-Serke
New articles in this journal are licensed under a Creative Commons Attribution 4.0 International License.

This journal is published by the University Library System of the University of Pittsburgh as part of its D-Scribe Digital Publishing Program and is cosponsored by the University of Pittsburgh Press 
Petrescu, Corina L. "Dobrenko, Evgeny and Natalia Jonsson-Skradol, eds. 2016. Socialist Realism in Central and Eastern European Literatures: Institutions, Dynamics, Discourses. London and New York: Anthem Press. 362 pp." Hungarian Cultural Studies. e-Journal of the American Hungarian Educators Association, Volume 12 (2019) DOI: 10.5195/ahea.2019.374

buzzword "socialist realism" was no exception. With only a succinct definition as "the new artistic method," it came to be, as Dobrenko and Jonsson-Skradol point out in their introduction to the volume, "an umbrella term for the ideologically correct spirit of literature and the arts" (2).

In structuring the volume, the editors had two goals in mind: to cover a wide range of cultures that fell under the Soviet influence and to conceptually and diachronically frame the contributions to the volume so as to initiate a debate on the Soviet era in East-Central Europe. They divide the book into three parts - "Institutions," "Dynamics" and "Discourses"- and within each parts they address the foundational concepts of both the theory and the practice of socialist realism. The contributions in the first part investigate the creation of the institutional framework for the literary fields in Eastern Europe in general (chapters 1 and 2) and more specifically in the Polish (chapter 3), Czech (chapter 4), Soviet (chapter 5), Bulgarian (chapter 6), and East German (chapter 7) cases. Tatiana V. Volokitina's contribution, "The Soviet Factor and the Institutionalization of Bulgarian Literature after World War II," is exemplary in its contention that, contrary to expectations, documents in Bulgarian archives clearly indicate that the country's "cultural Sovietization" (89) was anything but straightforward and that introducing Soviet cultural models to this Balkan country during the Stalinist years was neither a "unanimous and joyful adoption" nor a "relentless, unstoppable imposition" of Soviet paradigms (97). Rather, it was a "work in progress" (89) during which Soviet policies had to be adjusted to the local Bulgarian context.

In the second part, the individual authors look at the changes in the literary spheres of East Germany (chapter 8 and 9), Hungary (chapter 10 and 14), Romania (chapter 10), Croatia (chapter 11), Yugoslavia (chapter 12), and Slovakia (chapter 13). They consider these changes not only in the context of Soviet or national decision-making practices but also as outcomes of national political transformations leading the individual countries to revisit and/or revive earlier popular artistic theories and practices. Imre József Balázs illustrates processes of revision and revival of popular artistic theories and practices with regard to the literary avant-garde in both Hungary and Romania and argues that elements of avant-garde poetics continued in the socialist realist texts of formerly known avant-garde authors but now they became recontextualized, i.e., they "no longer carr[ied] the same message" because of their changed function (162). Making the transition from abstract, avant-garde literature to politically engaged, so-called progressive literature was thus "problematic, unsuccessful or imposed" (163) in the two cases under study. Melinda Kalmár's chapter makes obvious how the cultural debates, which began in the late 1940s and focused on the works and aesthetic theories of key figure of Hungarian culture such as Béla Bartók and György Lukács, demonstrated to artists and interested public alike that the Soviet authorities were not interested in "home-grown national aspirations" (219). Instead, they expected full compliance with their model of a strictly centralized cultural apparatus.

The volume's third part engages with the linguistic changes brought about by local transformations in the official discourse on Hungarian (chapter 15), Bulgarian (chapter 16), Soviet (chapter 17), Czech (chapter 18), Croatian (chapter 19), and East German (chapter 20) cultures. As the individual authors show, these changes determined how both literature producers, such as authors and presses, and consumers viewed and employed language to talk about the transformations in their societies and about their literatures. Tamás Schreibner builds on Kalmár's contribution to paint a new and intriguing portrait of György Lukács, by insisting that the critic's understanding of realism changed depending on the country in which he was active. While during his time in the Soviet Union he pleaded for a "reflective Marxist alternative 
to inflexible dogmatism" (237), in post-1945 Hungary he promoted a hegemonic, Stalinist cultural discourse. The so-called Lukács Debate (1949-50), which brought about his fall from grace, also marked a new shift in the socialist realist "critical idiom," one that made even Lukács's version "untenable" (254). In contrast to the Hungarian position, Nenad Ivić's investigations into the reshaping of the Croatian cannon between 1945 and 1955 sheds light on its "international and inclusive" (320) character despite its ideological contour. Relying on three literary reviews (Republika, Hrvatsko kolo and Izvor) and one cultural periodical (Djelo), Ivić presents Croatian literature of the time as "Weltliteratur with a perspective" (320) and objects to its complete dismissal as local on purely ideological grounds.

Volumes covering multiple cultures often face a problem, which afflicts this collection too: some cultures receive more attention than others. In this case, for example, there are four articles dedicated to the East German context, two and a half to the Hungarian, two to the Czech, Soviet, Bulgarian, and Croatian, one to the Yugoslav, Polish and Slovak, and merely half an article to the Romanian. It is, I find, unfortunate that it is always the same cultures that are examined minutely, while others receive only divided attention or are absent altogether: the volume contains no study or reference to Albanian culture, for example. Despite this shortcoming, Socialist Realism in Central and Eastern European Literatures argues successfully in favor of a new, in-depth view on socialist realism, which although short-lived as an institutional practice, proved tenacious as a linguistic and literary convention and as a marker of belonging, since "the discourse of socialist realism [was at all times] a discourse about socialist realism" (346) and the societies that embraced it. Socialist Realism proves a useful resource for graduate students and scholars interested in Eastern Europe in the second half of the twentieth century from various perspectives - literary, historical, political, cultural and sociological — and it opens the way for new insights into a troubling era. 